\title{
ROZŠIŘOVÁNÍ BUDOV S TÉMĚŘ NULOVOU SPOTŘEBOU ENERGIE A APLIKACE NÁKLADOVÉHO OPTIMA
}

\section{DEVELOPMENT OF NEARLY ZERO ENERGY BUILDINGS AND APPLICATION OF COST OPTIMUM}

\author{
Jiří Karásek ${ }^{1}$ Jan Veleba ${ }^{2}$ \\ ${ }^{1}$ SEVEn, The Energy Efficiency Center, Americká 17, Prague, 120 00, Czech Republic, \\ jiri.karasek@svn.cz, (+420 734319 322) \\ 2SEVEn, The Energy Efficiency Center, Americká 17, Prague, 120 00, Czech Republic, \\ jan.veleba@svn.cz, (+420 733746 624)
}

\begin{abstract}
Abstrakt - CZ
Článek se zabývá tématem budov s téměř nulovou spotřebou energie (nZEB) a nákladově optimální úrovní. Definice nZEB vychází z evropské a národní legislativy. Byl stanoven model pro porovnávání nákladů na výstavbu a provoz nZEB. Podíl nové nízkoenergetické výstavby na trhu v České republice je přibližně $4 \%$ ročně [1].

Klíčová slova - CZ

nákladově optimální úroveň, budovy s téměř nulovou spotřebou energie, energetická náročnost budov

\section{Abstract - EN}

The article deals with the topic of nearly Zero Energy Buildings (nZEB) and cost-optimal level. The definition of nZEB comes from the European and national legislation. A model was established to compare the costs of construction and operation of nZEB. The share of the new low-energy construction market is approximately $4 \%$ per annum in the Czech Republic [1].
\end{abstract}

\section{Keywords - EN}

cost-optimal level, nearly Zero Energy Buildings, energy performance of buildings

\section{JEL Classification}

O21 Planning Models, Planning Policy

O31 Innovation and Invention: Processes and Incentives

DOI: https://doi.org/10.14311/bit.2017.02.03

Editorial information: journal Business \& IT, ISSN 2570-7434, CreativeCommons license (c) (i) published by CTU in Prague, 2017, http://bit.fsv.cvut.cz/ 


\section{Úvod}

$V$ roce 2010 přijal Evropský parlament směrnici 2010/31/EU o energetické náročnosti budov (EPBD II) [2]. Členské státy měly za povinnost $v$ souladu s touto směrnicí zavést do roku 2012 legislativu vyžadující snížení energetické náročnosti nových i rekonstruovaných budov. Konkretizaci snížení energetické náročnosti $v$ budovách musí provést jednotlivé členské státy na základě nákladově optimální úrovně tak, aby legislativně vyžadovaná opatření byla nákladově efektivní. EU požaduje, aby byly vstupní údaje pro výpočty nákladově optimální úrovně nejpozději v roce 2017 aktualizovány [3].

\section{Rozvoj budov s téměř nulovou spotřebou energie}

Pro budovy s téměř nulovou spotřebou energie se běžně používá zkratka nZEB, která vychází $z$ anglického nearly Zero Energy Buildings. Mezi takové budovy patří jak novostavby, tak i rekonstrukce budov stávajících. Definici nZEB na evropské úrovni určuje Směrnice 2010/31/EU, o energetické náročnosti budov (EPBD II) [2].

Podle článku 2 bodu 2) směrnice 2010/31/EU se rozumí:

„budovou s téměř nulovou spotřebou energie” budova, jejiž energetická náročnost určená podle prílohy I je velmi nízká. Téměř nulová či nízká spotřeba požadované energie by měla být ve značném rozsahu pokryta z obnovitelných zdrojů, včetně energie z obnovitelných zdrojů vyráběné v mistě či v jeho okoli;

V článku 9 odstavce 1 směrnice 2010/31/EU je uveden časový rámec, do kterého členské státy zajistí, aby:

a) do 31. prosince 2020 všechny nové budovy byly budovami s téměř nulovou spotřebou energie a

b) po dni 31. prosince 2018 nové budovy uživané a vlastněné orgány veřejné moci byly budovami s téměr̆ nulovou spotřebou energie.

České národní požadavky na nZEB jsou definovány ve vyhlášce č. 78/2013 Sb.[4]. Takové budovy nesmí dosahovat (dle $\S 6$ odst. 1) vyšších hodnot energetických ukazatelů uvedených v § 3 odst. 1 písm. b), c) a e) než referenční budova. Jedná se o ukazatele neobnovitelné primární energie, celkové dodané energie a průměrného součinitele prostupu tepla. Pro budovy s téměř nulovou spotřebou energie je dále definován redukční činitel pro výpočet referenční hodnoty průměrného součinitele prostupu tepla 0,7 . Referenční hodnoty průměrného součinitele prostupu tepla se vypočítají z požadovaných hodnot uvedených v ČSN 730540-2:2012 [5].

Nově postavené či rekonstruované budovy musí dosáhnout standardu nZEB, který musí být doložen kladným závazným stanoviskem Státní energetické inspekce (SEI) v rámci stavebního řízení v těchto termínech pro veřejné budovy, jejíž energeticky vztažná plocha je:

- $\operatorname{nad} 1500 \mathrm{~m}^{2}$ od 1. ledna 2016,

- nad $350 \mathrm{~m}^{2}$ od 1. ledna 2017,

- méně než $350 \mathrm{~m}^{2}$ od 1 . ledna 2018.

Pro všechny ostatní budovy platí stejné požadavky, jen s dvouletým zpožděním. U všech ostatních budov opět záleží na velikosti energeticky vztažné plochy:

- nad $1500 \mathrm{~m}^{2}$ od 1 . ledna 2018,

- nad $350 \mathrm{~m}^{2}$ od 1. ledna 2019,

- méně než $350 \mathrm{~m}^{2}$ od 1 . ledna 2020 [6].

Od začátku ledna 2018 v ČR již platí požadavek na budovy s téměř nulovou spotřebou energie pro všechny nové a nově rekonstruované budovy ve správě veřejných institucí a orgánů veřejné moci. 
Zároveň se požadavek na nZEB nově vztahuje na všechny ostatní velké budovy s energeticky vztažnou plochou nad $1500 \mathrm{~m}^{2}$. V následujících letech proběhnou v ČR ještě dvě další vlny povinného zavádění standardů nZEB dle velikosti objektů a od roku 2021 tato povinnost bude platit ve všech členských státech Evropské unie. $V$ roce 2050 by měly budovy splňující standard nZEB tvořit nejméně $25 \%$ podíl na stavebním fondu $v$ EU.

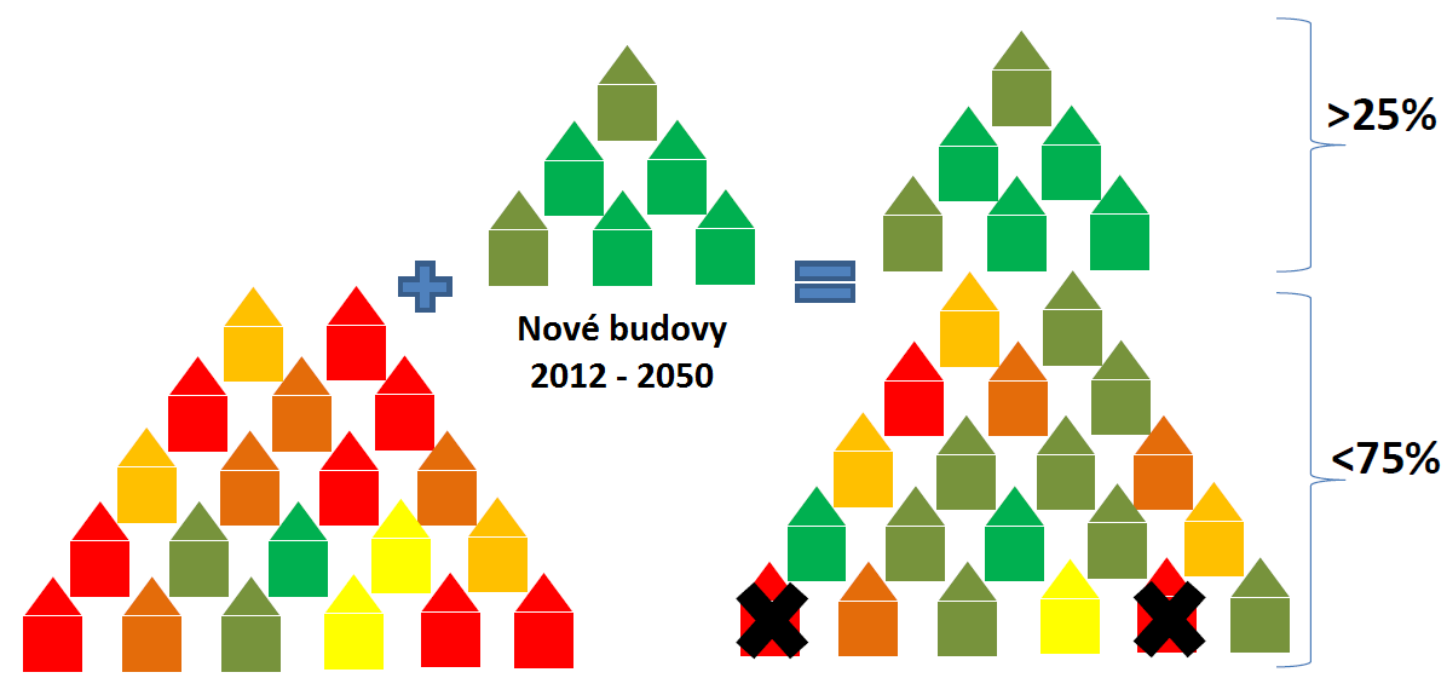

Současný stavební fond

Stavební fond $\mathrm{v}$ roce 2050

Obr. 1 Rozšíření budov s téměř nulovou spotřebou energie v EU do roku 2050

Zdroj: [1]

\section{Nákladově optimální úroveň}

Pojem nákladově optimální úroveň má sloužit ke stanovení ekonomicky efektivních minimálních legislativních požadavků na nově budované nebo rekonstruované budovy se zřetelem na co nejnižší celkové náklady a při minimalizovaném vlivu na životní prostředí, tj. při minimální spotřebované primární energii [7].

Srovnávací analýza a hledání nákladového optima měly za cíl najít oblast nákladově optimálních řešení pro dané okrajové (zejména technické a ekonomické) podmínky. Nákladově optimální řešení je takové, kterému odpovídají nejnižší měrné celkové náklady za celé definované hodnotící období. Tomuto řešení pak odpovídá určitá hodnota měrné primární energie [3], [8]. 


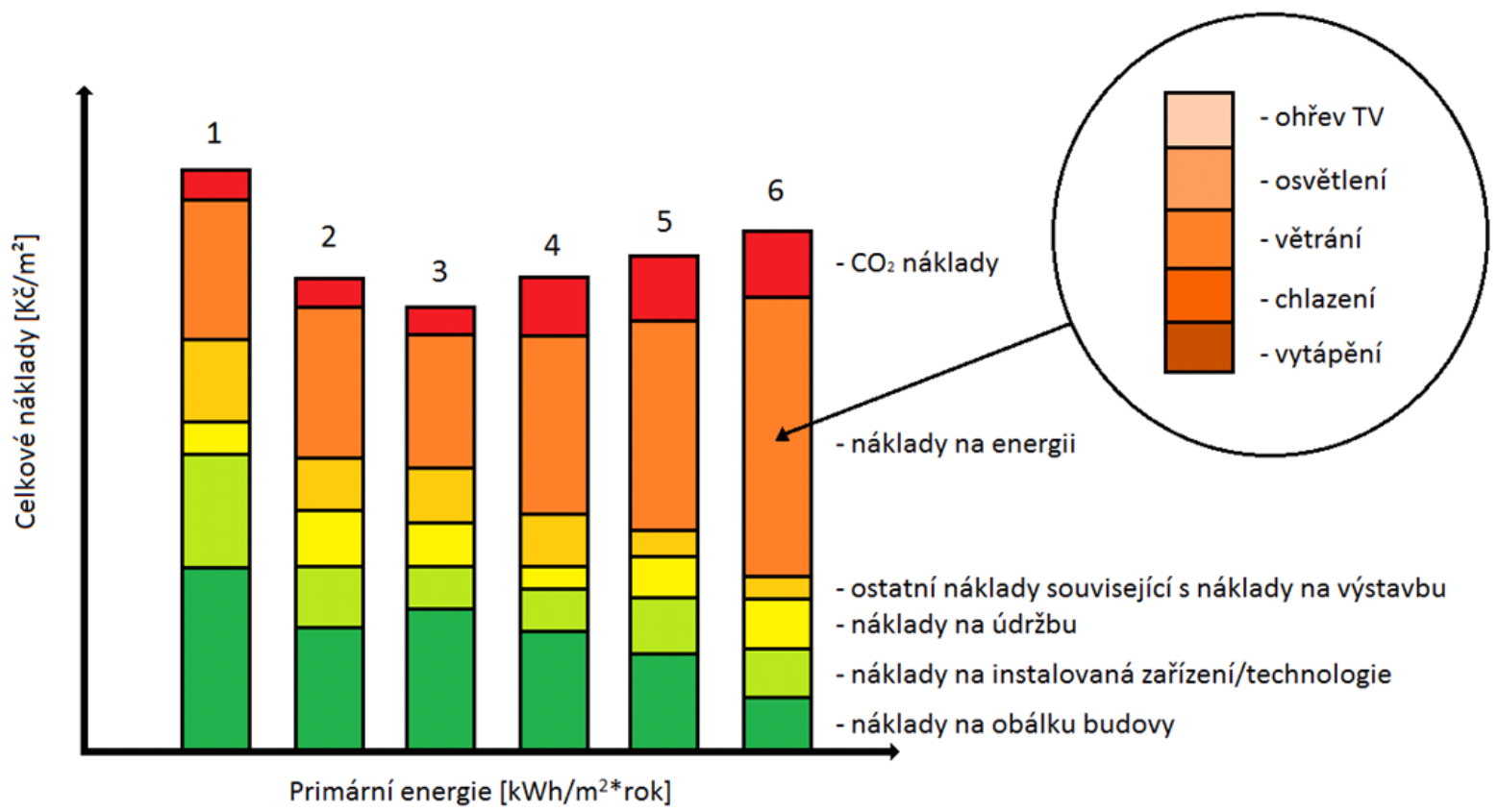

Obr. 2 Obecný princip hledání nákladového optima

Zdroj: [1]

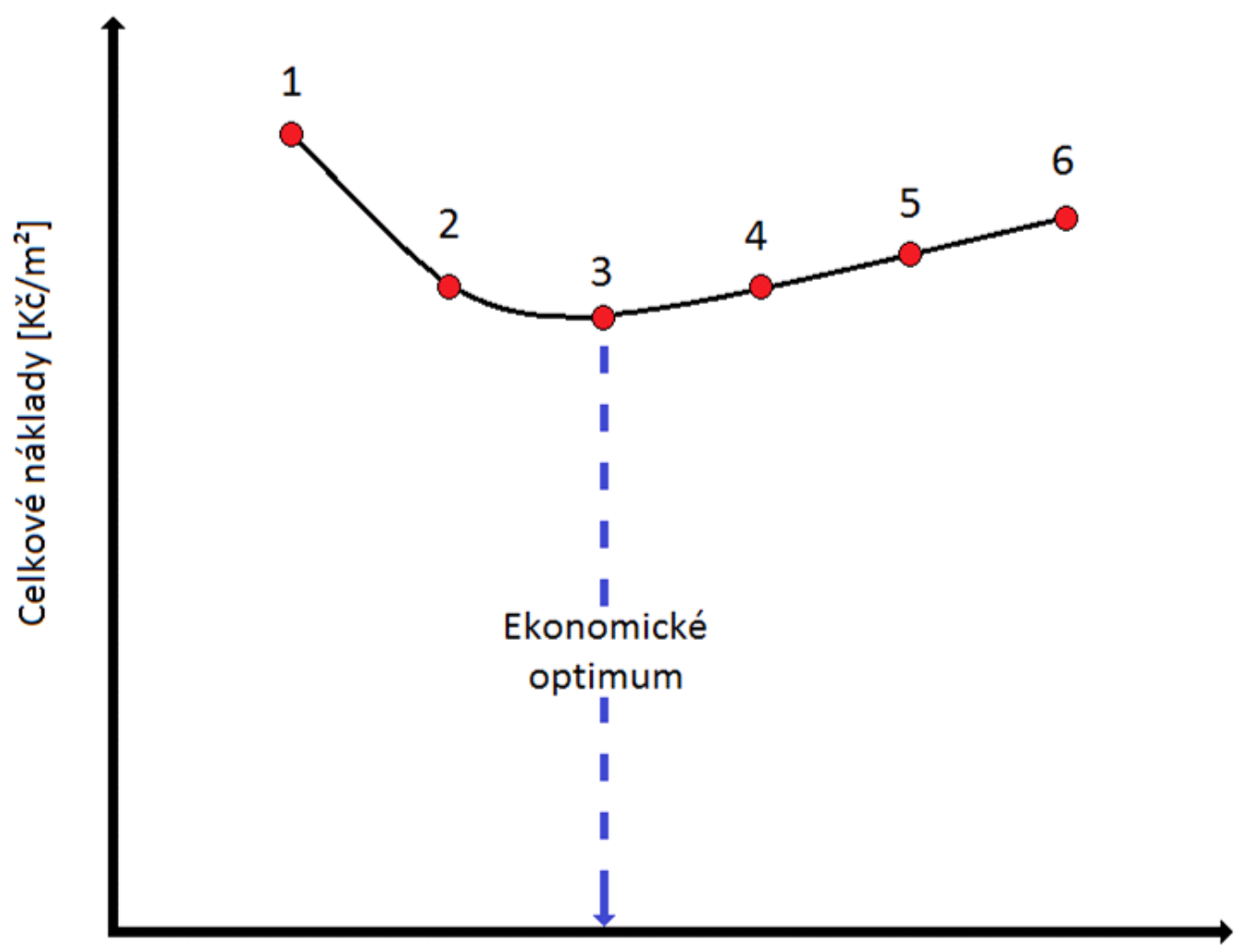

Primární energie $\left[\mathrm{kWh} / \mathrm{m}^{2 *}\right.$ rok]

Obr. 3 Základní závislost celkových měrných nákladů a primární energie pro hledání nákladově optimální úrovně

Zdroj: [1] 


\section{Aktualizace nákladově optimální úrovně}

První výpočet nákladově optimální úrovně v roce 2012 byl proveden pro dvanáct různých referenčních budov od malého rodinného domu po velké budovy občanské vybavenosti. Mezi referenční budovy byly zahrnuty novostavby i rekonstrukce budov. Pro stanovení nákladového optima byly referenčním budovám variantně stanoveny další parametry jako např. odlišné hodnoty součinitele prostupu tepla obvodových konstrukcí, různé zdroje vytápění, způsoby ohřevu vody, systémy větrání, osvětlení atd [9].

$\checkmark$ roce 2016 byl proveden nový výpočet nákladového optima, který vycházel ze stejné metodiky jako v roce 2012, avšak veškeré vstupní parametry výpočtů musely být aktualizovány [11].

Vzhledem k neustálému vývoji cen stavebních prvků, materiálů a prací, byl proveden podrobný průzkum stavebního trhu. Cílem bylo získat aktuální ceny pro potřeby výpočtů cen různých energeticky efektivních opatření. Aktualizovány byly kromě cen stavebních opatření i další parametry jako sazba DPH, ceny paliv a energií i specifikace jednotlivých systémů technického zařízení budov.

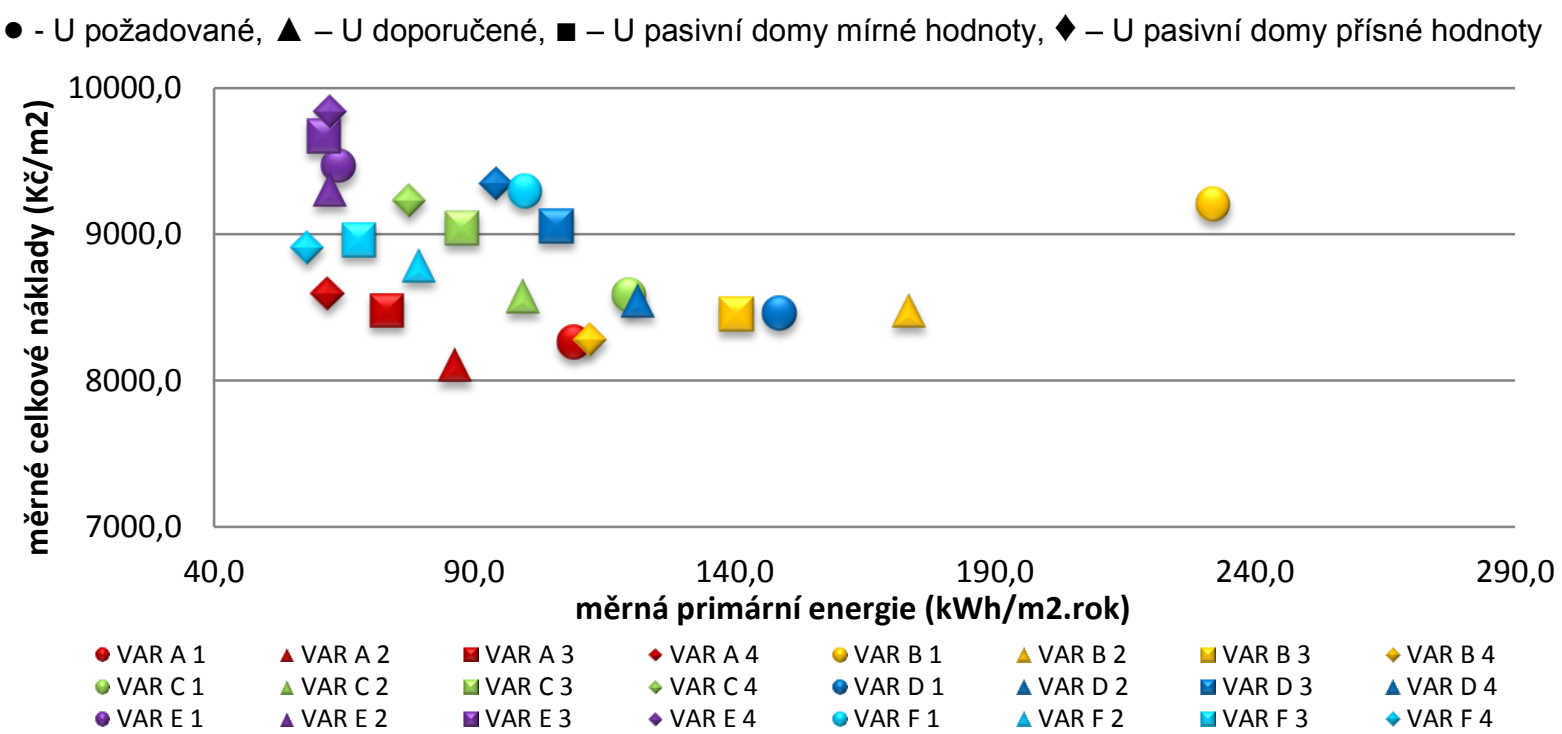

Obr. 4 Ukázka variantního výpočtu pro hledání nákladově optimální úrovně v závislosti na energetickém standardu obálky budovy a zdroje tepla (odlišné barvy označují různé druhy zdrojů tepla) Zdroj: [3]

Jako optimální řešení novostavby rodinného domu se jeví efektivnost obálky budovy na úrovni doporučených hodnot součinitele prostupu tepla a jako tepelné zdroje jsou nejvhodnější kotle s vysokou účinností (plynový kotel) a tepelné čerpadlo. Rekonstrukce rodinných i bytových domů vykazovaly obdobné výsledky. Jako optimální řešení vycházelo zefektivnění obálky budovy na doporučené hodnoty součinitele prostupu tepla $U$ a využití zdrojů tepla s vysokou účinností.

\section{Hlavní změny pro rok 2016}

Zásadní změnou pro rok 2016 byly trendy poklesu cen stavebních materiálů a zároveň pokles cen energie. Uvedené, co do výpočtu nákladového optima, protichůdné trendy zachovávají v převážném počtu variant doporučené hodnoty součinitele teplené vodivosti jako nákladově optimální. Souhlasně se pak tyto trendy chovají při vyhodnocení celkových nákladů, které významně posunují níže. Lze říci, že celkové náklady staveb od roku 2012 výrazně poklesly o to v řádu 10 až $30 \%$.

V roce 2016 zaznamenaný pokles DPH ovlivnil oproti roku 2012 celkové náklady, nicméně nevedl k posunu optimality jednotlivých způsobů vytápění nebo variant obálky budovy. 
Většina variant opaření a jejich kombinací je v porovnání s výsledky z roku 2012 levnějších a to především díky podstatně nižším nákladům na stavební opatření. Mezi výsledky v letech 2012 a 2016 Ize pozorovat rozdíly. Ty jsou způsobeny odlišnými cenami jednotlivých stavebních opatření, elektřiny a paliv. Vliv na rozdílné výsledky má také jiný přístup k využití nuceného větrání a výpočtům tepelných zisků.

Nucené větrání s rekuperací bylo na rozdíl od roku 2012 ve výpočtech uvažováno pouze pro topné období. Tepelné zisky byly ve výpočtech oproti roku 2012 uvažované podstatně nižší (solární zisky a teplené zisky z osvětlení byly v pưvodních výpočtech nadhodnocené) [3].

\section{Vyhodnocení a závěry}

Na základě provedených mnoha desítek různých výpočtů na konkrétních budovách Ize odvodit některé závěry potvrzené většinou výsledků. Hlavní z nich jsou tyto:

- Nákladově optimální úroveň parametrů obalových konstrukcí nových budov se obvykle pohybuje kolem doporučených hodnot podle normy. To je zapříčiněno vlivem poklesu cen energie a zároveň vlivem poklesu cen opatření, které neumožnily posun $\mathrm{k}$ jiné obálce budovy. Zároveň nedošlo k zásadní změně výhodnosti určitého způsobu vytápění.

- Nákladově optimální úroveň parametrů se v prrípadě změn dokončených staveb (rekonstrukcí) obvykle pohybuje kolem doporučených hodnot podle normy [5].

- Z části výsledků výpočtů pro vytápění vyplývá, že nastavení referenčních hodnot distribuce a sdílení a činitel prostupu slunečního záření, umožňují dosahovat úspor pro hodnocené varianty $v$ porovnání s hodnotou referenční. To umožňuje větší variabilitu možných řešení. Zároveň toto mírnější nastavení neklade takový důraz na extrémně nízké hodnoty v oblasti vytápění - avšak ten je kompenzován nastavením požadavků na obalové konstrukce budovy.

- Významný vliv na spotřebu energie na vytápění má výše uvažované účinnosti osvětlení, díky které jsou generovány významné vnitřní tepelné zisky, snižující výpočtovou spotřebu energie na vytápění. Pro rok 2016 byly dopady osvětlení sniženy tak aby odpovídaly dnešním dramatickým změnám v oblasti osvětlení.

- Nucená výměna vzduchu s rekuperací významně sniží parametry dodané energie, již méně energie primární. Optimalita řešení může být významně ovlivněna možností instalace rekuperace (zejména trubních rozvodů) ve stávajících budovách. Vyhodnocením přístupu k větrání (vyhodnocení variant nuceného a přirozeného) Ize říci, že náklady variant přirozeného větrání jsou nižší než náklady variant nuceného větrání. Přínosy nuceného větrání se tak nezobrazují ve výpočtu celkových nákladů. Nucené větrání má význam zejména s ohledem na zajištění dlouhodobě kvalitního vnitřního prostředí a komfortu provozování budovy.

- Kvalita osvětlení vykazuje značný vliv na výsledek výpočtu, přitom v př́padě rezidenčních objektů je minimální možnost ovlivnit kvalitu světelných zdrojů a svítidel projektem. S ohledem na vlivy současných trendů osvětlení byly vstupy $v$ této oblasti změněny. $V$ případě nerezidenčních budov je referenční hodnota měrného príkonu na osvětlenost $0,1 \mathrm{~W} /\left(\mathrm{m}^{2} . \mathrm{Ix}\right)$ vysoká. Tím dochází $\mathrm{k}$ výpočtu velmi vysoké referenční hodnoty dodané energie na osvětlení.

- Diskontní sazby byly ve výpočtu realizovány identicky s rokem 2012 z důvodu možného porovnání. Proveden byl i výpočet v takzvaných stálých cenách s uvedením diskontní sazby ve výši $2 \%$ a růstu cen energie také $2 \%$. Výpočet však nevedl k posunu nákladového optima. $K$ posunu by vedly až významnější změny volených parametrů.

- Další výpočty byly rozšířeny o solární kolektory. S jejich zahrnutím se posouvá do nákladového optima vytápění elektrickými prrímotopy. 
Pro jednotlivé zdroje vytápění se měrná neobnovitelná primární energie významně neliší natolik, aby nebylo možné př́padné negativní rozdíly oproti referenční hodnotě, tj. požadavku, kompenzovat užitím účinnějšíddalší technologie v systému vytápění nebo přípravy teplé vody včetně obnovitelných zdrojů energie, užitím kvalitnějšího osvětlení. Významný rozdíl ve výsledcích představuje užití zdroje tepla na vytápění a/nebo přípravu teplé vody na elektrickou energii, kde je nutné rozdíly kompenzovat obvykle kombinací užití obnovitelného zdroje energie a použitím kvalitnějších konstrukcí obálky budovy.

Z hlediska citlivosti výpočtů na různé vstupní parametry je pro nové i stávající budovy charakteristické, že měrné celkové náklady jsou ovlivněny zejména uvažovaným růstem cen energií a diskontní sazbou za definované hodnotící období (tj. 30 let, resp. 20 let u komerčních objektů), dále pak vstupními investičními náklady. Rozdílná doba životnosti jednotlivých prvků je kompenzována tzv. zbytkovou hodnotou ve výpočtu, čímž jsou tyto rozdíly narovnány. Při uvážení neextrémních hodnot růstu cen energií a diskontních sazeb se výsledky výpočtů v absolutních hodnotách liší, nicméně při vzájemném porovnání technických řešení se pořadí ne/výhodnosti jednotlivých variant řešení téměř nemění. $Z$ tohoto pohledu Ize říci, že pokud v 30letém výhledu (hodnotící období většiny budov) vezmeme v úvahu neextrémní hodnoty potenciálního ekonomického vývoje, jsou výsledky nákladové optimalizace stabilní [3].

Cíle České republiky v oblasti zvyšování energetické účinnosti a zvyšování počtu nZEB v podstatě vyplývají jen z požadavků evropských směrnic. Postrádány jsou vyšší národní ambice výrazně nad rámec stanovených cílů Evropské unie. Značné nedostatky jsou shledávány v informovanosti a vzdělávání odborníků i širší veřejnosti ve spojitosti s nZEB. Vzhledem k velikosti změny, kterou je povinnost stavět od roku 2021 pouze budovy s téměř nulovou spotřebou energie, se příprava především stavebních podniků i vzdělávání nových stavebních odborníků jeví jako ne zcela dostačující. Česká republika by si měla vzít vhodné př́iklady ze zahraničí a implementovat je do svých plánů a strategií. $V$ současné době probíhají mezinárodní projekty, $v$ nichž má ČR své zastoupení, které by měly zlepšit informovanost širší veřejnosti a municipalit a také zvýšit odborné dovednosti a vědomosti pracovníkům ve stavebnictví v oblasti nZEB a nízkoenergetické výstavby obecně [1]. Jedním takovým mezinárodním projektem je například projekt Train-to-NZEB. $V$ rámci tohoto projektu vzniká v Praze vzdělávací centrum, které od března 2017 nabídne školicí kurzy zaměřené na zvýšení odborné kvalifikace v oblasti nZEB.

\section{References}

[1] VELEBA, J., Ekonomika budov s téměř nulovou spotřebou energie, Diplomová práce, ČVUT, Praha, 2016.

[2] Směrnice Evropského parlamentu a Rady 2010/31/EU (EPBD II), o energetické náročnosti budov, 19. květen 2010, Úřední věstník Evropské unie.

[3] KARÁSEK, J., MAROUŠEK, J. KALOČAI, L., VELEBA, J., ANISIMOVA, N.: Aktualizace vstupů nákladového optima budov v ČR podle článku 5 směrnice EPBD II, SEVEn, Praha, prosinec 2016.

[4] Vyhláška o energetické náročnosti budov č. 78/2013 Sb., březen 2013.

[5] ČSN 730540 Tepelná ochrana budov, část 1: Terminologie, 2005; část 2: Požadavky, 2011; část 3: Návrhové hodnoty veličin, 2005; část 4: Výpočtové metody, 2005.

[6] Zákon č. 318/2012 Sb., kterým se mění zákon č. 406/2000 Sb., o hospodaření energií, ve znění pozdějších předpisů, ze dne 19. července 2012.

[7] MAROUŠEK, J., ZAHRADNÍK, P., ŠESTÁKOVÁ, Z., KARÁSEK, J., Prezentace výsledků výpočtů nákladové optimalizace při výstavbě a rekonstrukci budov v ČR podle implementované Směrnice EPBD II, SEVEn, Praha, 2013.

[8] HROMADA, E. Life Cycle Costing from the Investor's and Facility Manager's Point of View. In: SOJKOVÁ, K., et al., eds. Central Europe towards Sustainable Building 2016 - Innovations for Sustainable Future. Central Europe towards Sustainable Building 2016 Innovations for Sustainable Future. Prague, 22.06.2016 - 24.06.2016. Praha: GRADA PUBLISHING. 2016, pp. 1374-1380. 1st edition, Prague, June 2016, Complete edition - printed version + Flash disk with full paper version. ISBN 978-80-271-0248-8. Available from: http://cesb.cz/ 
[9] SCHNEIDEROVÁ HERALOVÁ, R. Life cycle costing within infrastructure projects. In: HÁJEK, P., et al., eds. Central Europe towards Sustainable Building 2016 - Innovations for Sustainable Future. Central Europe towards Sustainable Building 2016 Innovations for Sustainable Future. Prague, 22.06.2016 -

24.06.2016. Praha: GRADA PUBLISHING. 2016, pp. 1468-1475. 1st edition, Prague, June 2016, Complete edition - printed version + Flash disk with full paper version. ISBN 978-80-271-0248-8.

[10] DANIEL MACEK (2016). Criteria for national rating system for buildings SBToolCZ. Business \& IT, Vol. VI(2), pp. 2-9, DOI: https://doi.org/10.14311/bit.2016.02.01.

[11] KONASOVA SARKA, REIS VAGNER DA SILVEIRA (2016). Green roofs: roof system reducing heating and cooling costs. Business \& IT, Vol. VI(1), pp. 60-65, DOI: https://doi.org/10.14311/bit.2016.01.06. 